\title{
How groundwater time series and aquifer property data explain heterogeneity in the Permo-Triassic sandstone aquifers of the Eden Valley, Cumbria, UK
}

\author{
Alex Colyer ${ }^{1,2} \cdot$ Adrian Butler $^{1} \cdot$ Denis Peach $^{1,2} \cdot$ Andrew Hughes $^{2}$
}

Received: 6 April 2021 / Accepted: 3 December 2021 / Published online: 31 December 2021

(c) The Author(s) 2021

\begin{abstract}
A novel investigation of the impact of meteorological and geological heterogeneity within the Permo-Triassic Sandstone aquifers of the River Eden catchment, Cumbria (UK), is described. Quantifying the impact of heterogeneity on the water cycle is increasingly important to sustainably manage water resources and minimise flood risk. Traditional investigations on heterogeneity at the catchment scale require a considerable amount of data, and this has led to the analysis of available time series to interpret the impact of heterogeneity. The current research integrated groundwater-level and meteorological time series in conjunction with aquifer property data at 11 borehole locations to quantify the impact of heterogeneity and inform the hydrogeological conceptual understanding. The study visually categorised and used seasonal trend decomposition by LOESS (STL) on 11 groundwater and meteorological time series. Decomposition components of the different time series were compared using variance ratios. Though the Eden catchment exhibits highly heterogeneous rainfall distribution, comparative analysis at borehole locations showed that (1) meteorological drivers at borehole locations are broadly homogeneous and (2) the meteorological drivers are not sufficient to generate the variation observed in the groundwater-level time series. Three distinct hydrogeological regimes were identified and shown to coincide with heterogeneous features in the southern Brockram facies, which is the northern silicified region of the Penrith Sandstone and the St Bees Sandstone. The use of STL analysis in combination with detailed aquifer property data is a low-impact insightful investigative tool that helps guide the development of hydrogeological conceptual models.
\end{abstract}

Keywords Heterogeneity · Time series analysis · Groundwater statistics · Conceptual models · UK

\section{Introduction}

River catchments are heterogeneous by nature, which poses a challenge to both hydrologists and hydrogeologists. Hydrogeological heterogeneity is present at all scales, from the pore to the catchment, and can be categorised as (1) meteorological, which is observed in spatial and temporal variation in rainfall or evaporation and (2) geological, which is expressed in both superficial and lithified strata. Freeze and Cherry (1979) subdivided geological heterogeneity into layered, discontinuous and trending. Layered heterogeneity occurs in strata that contain alternating beds of lithologies

\footnotetext{
Alex Colyer

asc116@ic.ac.uk

Imperial College London, London, UK

2 British Geological Survey, Nottingham, UK
}

with different hydraulic properties, such as sandstone and mudstone. Discontinuous heterogeneous features include faults and lithological boundaries. Trending features show systematic variation in hydraulic properties, such as those found as the result of sedimentation processes in deltas or alluvial fans. These heterogeneities impact the surface and subsurface hydrology by imposing controls on the water cycle, the importance of which depends on the scale of investigation. To manage water resources sustainably on a catchment scale, the impacts of these heterogeneities need to be understood and incorporated into a conceptual model of surface-water and groundwater flow. Researchers have investigated the impact of heterogeneity on the hydrological cycle using a range of methods. Specifically, studies that investigate meteorological heterogeneity include multiscale techniques that interrogate variation in distributed and point meteorological data (e.g. Aalto et al. 2017) and modelling of surface energy balances (e.g. Raupach and Finnigan 1995). 
In comparison, geological heterogeneity investigations include (1) field work (e.g. tracer mixing experiments and outcrop mapping) and extensive hydrogeological-property measurement campaigns at a range of measurement scales (e.g. analysis of core samples) and (2) modelling investigations that, for example, combine deterministic techniques to define discontinuous heterogeneity paired with continuous geostatistical techniques to represent trend and layered heterogeneity (Bianchi et al. 2015). These techniques are data hungry, and collection of these data is time-consuming and expensive. As such, methods to aid the interpretation of groundwater-level time series that integrate multiple hydrological processes have increased in popularity.

Statistically, hydrological time series can be treated as sequences of random variables that can be interpreted through time series analysis. The groundwater system is conceptualised as a filter that transforms an input signal (e.g. rainfall) into an output signal (e.g. groundwater-level fluctuations) through the application of a transfer function (Delbart et al. 2014). The interpretation of these mathematical relationships can aid in understanding the functioning, organisation, and structure of aquifers. Time series analysis techniques can offer a systematic and quantitative approach to evaluating groundwater systems. Techniques that have routinely been used to characterise groundwater systems are extensively described by Box et al. (2016). Groundwater hydrograph analysis has been used to estimate recharge (Moon et al. 2004; Cai and Ofterdinger 2016) and change in aquifer storage (Boutt 2017), and to define distinct hydrological zones within aquifers (Bloomfield et al. 2015; Lafare et al. 2016). These techniques benefit from the growing availability of high-temporal-resolution (i.e. $<1$ day) groundwater-level observations. These time series are the product of heterogeneities at the surface and within the subsurface and as such can provide insight into hydrological functioning. However, relatively few systematic groundwater-hydrograph analysis studies have been used to investigate temporal and spatial heterogeneities (Giese et al. 2020). Those that have been conducted include Bloomfield et al. (2015), who showed that, through cluster analysis techniques to classify standardised groundwater-level hydrographs and correlation with precipitation, statistically defined clusters of groundwater-level fluctuations were independent of meteorology and were primarily a function of catchment and hydrogeological factors such as unsaturated zone thickness at individual boreholes. Kovács et al. (2015), on the other hand, used dynamic factor analysis to quantify the effect of diverting the River Danube in Hungary, identifying a two-component signal in observation boreholes effected, and an increased effect of precipitation that previously had been suppressed by the river. Lafare et al. (2016) used a combination of seasonal trend decomposition by LOESS (STL), auto-correlation and cluster analyses to improve the conceptual understanding of the Permo-Triassic Sandstone aquifers of the Eden Valley, Cumbria, UK. They concluded that differences in bedrock characteristics between formations appear to influence groundwater fluctuations. The work reported here utilises high-resolution groundwater-level observations covering an extended time period (2000-2018) to investigate and compare the impact of meteorological and geological heterogeneity on groundwater-level fluctuations in the Permo-Triassic Sandstone aquifers, which comprise part of the River Eden Catchment in Cumbria. Lafare et al. (2016) showed that through the analysis of groundwaterlevel fluctuations, between 2000 and 2012, the differences in rock properties between the two major aquifer units appear to influence groundwater-level response to hydrological drivers. This work builds on that of Lafare et al. (2016) by evaluating the impact of geological heterogeneity within aquifer units and considering the impact of heterogeneous meteorological drivers on the groundwater-level time series. Additionally, this work extends the groundwater time series studied by Lafare et al. (2016) by 6 years, which includes two large-scale flooding events in 2012 and 2015.

The overarching aim of this work is to highlight the impact of heterogeneity on the groundwater cycle by investigating groundwater dynamics in combination with meteorological time series (rainfall, actual evaporation, and effective rainfall) and detailed hydrogeological data (borehole logs and aquifer property data). By exploring the linkages between these sources of heterogeneity the effect that they impose on groundwater will be identified within the PermoTriassic sandstone aquifers of the Eden Valley, Cumbria.

\section{Study area description}

Located in northwest England (UK), the River Eden Catchment covers approximately $2,400 \mathrm{~km}^{2}$. The river channel is approximately $145 \mathrm{~km}$ long and discharges into the Solway Firth (see Fig. 1). Its main urban area is the city of Carlisle, where the average discharge at Sheepmount is $52 \mathrm{~m}^{3} / \mathrm{s}$ (Leedal et al. 2013). It is apredominantly rural catchment with livestock farming being the dominant land use. There is marked spatial contrast in land use from peat moor uplands to pasture in the lowlands, and elevation varies from $946 \mathrm{~m}$ above ordnance datum (AOD) to sea level. The elevation differences between the Lake District to the south-west, the Pennines to the east, and the Eden Valley generate an orographic effect (Fig. 1), which is shown by large variations in spatial rainfall distribution between the uplands and valley bottom, that receive average annual totals of 2,000 and 650 $\mathrm{mm}$, respectively.

The Eden Valley Catchment (often referred to as Vale of Eden Basin) is $50 \mathrm{~km}$ long and between 5 and $15 \mathrm{~km}$ wide (Allen et al. 2010). The Permo-Triassic sedimentary units were deposited in a half-graben structure that gently dips $10^{\circ}$ 
Fig. 1 Simplified bedrock geology map of the Eden Valley, Cumbria, UK (from the British Geological Survey 1:50,000 map). Location of observation boreholes (green included in current study, blue excluded). For consistency, borehole numbering follows that of Lafare et al. (2016). () UKRI 2021, as represented by BGS and contains Ordnance Survey data (C) Crown copyright and database right 2021

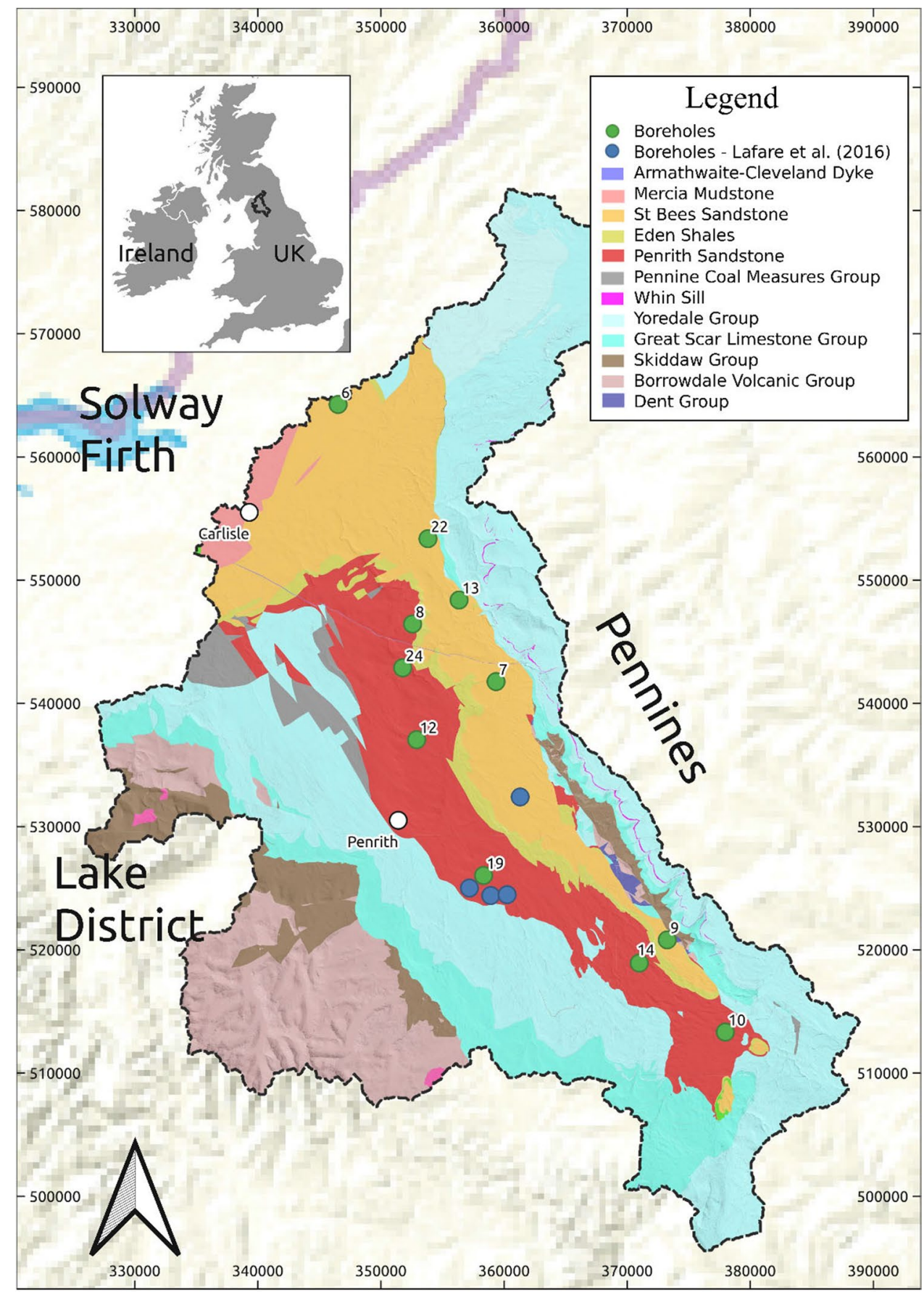

to the northeast, which is fault-bound to the south and east by the Dent and Pennine fault systems, respectively (Arthurton and Wadge 1981). The geology of the Eden Catchment is comprised of the basal Lower Carboniferous succession characterised as thickly bedded limestones that outcrop in the headwaters of the Eden Catchment, which have a welldeveloped epikarst system (Younger and Milne 1997). These strata are overlain by the Yoredale Group which, in the northern extent of the catchment, is succeeded by the Millstone Grit Group (Hughes 2003a; Stone et al. 2010). The
Carboniferous Coal Measures Group is the highest stratigraphic Carboniferous unit but only outcrops in the west of the catchment. The Carboniferous strata are overlain by the Permo-Triassic deposits, which comprise the Permian Penrith Sandstone, Permian Eden Shales and Triassic St Bees Sandstone. The Penrith and St Bees Sandstones are the major aquifers in the region and are separated both geologically and hydrogeologically by the Eden Shales. The Penrith Sandstone contains three lithologies. The Brockram facies, which is a basal breccia deposit that is present at the 
basin margins (Arthurton and Wadge 1981) and overlain by aeolian sandstone. In addition, in the northern region of the Penrith Sandstone outcrop, the upper $100 \mathrm{~m}$ of stratigraphy have undergone secondary silicification within massive sandstone beds, which causes higher relief than to the south (Ingram 1978; Hughes 2003b; Stone et al. 2010). These silicified sandstones are hard and have very low porosity and hydraulic conductivity (Allen et al. 1997; Younger and Milne 1997; Butcher et al. 2008). The Eden Shales overlie the Penrith sandstone and their thickness is highly variable, ranging from 45 to $180 \mathrm{~m}$ (Arthurton and Wadge 1981). The Eden Shales are overlain by the Triassic St Bees Sandstone, which is a thick fluviatile deposit (Allen et al. 1997; Medici et al. 2015). Quaternary deposits up to $30 \mathrm{~m}$ thick overlie most of the valley (ca. 75\%). These deposits comprise complex interdigitations of sand, gravel, silt and clay that Allen et al. (2010) broadly characterised as till, glaciofluvial outwash, river terrace deposits and alluvium. Detailed geological descriptions of the Eden Valley are published in Allen et al. (1997), (2010), and Lafare et al. (2014). Direct recharge to the underlying aquifer is hypothesised to follow a 'piston flow' mechanism through the Quaternary deposits and recharge is thought to occur preferentially through windows in the Quaternary deposits and higher-conductivity (thin fractured) zones (Butcher et al. 2003, 2006); however, the rate and spatial distribution of recharge remains uncertain. Connectivity between the surface water and groundwater at both the regional and local scale remains uncertain.

Heterogeneity in hydrogeology is defined as the spatial variation and directional trend in aquifer property values (Hiscock 2014). Heterogeneity exerts a control on many processes within the hydrogeological cycle: specifically, recharge and groundwater flow. The variation in hydraulic properties is particularly important for contaminant transport, hydrocarbon exploitation, water resources management and groundwater flooding.

Sources of heterogeneity in the Eden Valley can be subdivided into meteorological heterogeneity observed in rainfall, and geological heterogeneity in the Quaternary and bedrock hydraulic property variation. Within the Eden Valley, hydrological heterogeneity occurs within the spatial distribution of rainfall, which is strongly controlled by topography, with 3 times the annual valley rainfall occurring in the headwaters and topographic highs on the east and west sides of the valley. Geological heterogeneity within the Quaternary deposits is expressed through the complex geometry of lithological units and their highly variable hydrogeologic properties (Butcher et al. 2003). Butcher et al. (2008) have shown through tracer experiments that the complex superficial deposits impose a control on recharge processes. Within the Permo-Triassic aquifer units, heterogeneity is expressed in the wide range of aquifer property values measured, with transmissivity estimates ranging from 3 to $3,300 \mathrm{~m}^{2} /$ day
(Allen et al. 1997). Younger and Milne (1997) subdivide aquifer properties into the distinct Penrith Sandstone and St Bees Sandstone units, with transmissivity in the ranges $13-3,300 \mathrm{~m}^{2} /$ day and $202-526 \mathrm{~m}^{2} /$ day for the Penrith and St Bees sandstones, respectively. However, these data do not describe the variation of aquifer properties spatially. Lafare et al. (2016) apply STL analysis (Cleveland et al. 1990) to groundwater-level time series and identify clusters of boreholes with similar statistical features. However, the work of Lafare et al. (2016) focused on the two-dimensional (2D) distribution of categorisation, rather than the impact of heterogeneity in three-dimensions. While contributing to the conceptual understanding of the catchment, these studies have largely focused on heterogeneity factors in isolation, failing to explore the combined effects of heterogeneity on groundwater levels with detailed aquifer property data in three-dimensions.

\section{Materials and methods}

The impact of different sources of heterogeneity on the groundwater cycle will be investigated visually and statistically by applying the STL analysis to meteorological and groundwater time series to identify similarities. Followed by a detailed examination of aquifer properties in three-dimensions.

\section{Data}

Groundwater-level data for the 26 observation boreholes were obtained from the Environment Agency, 18 of which have been continuously monitored since 2005 (Fig. 1). Of the boreholes analysed by Lafare et al. (2016), 6 of the 18 were adjacent to the River Leith; this could potentially skew the results in favour of identifying proximity to rivers as a key driver in groundwater-level fluctuation control. Therefore, this research selected boreholes that proportionally represent variable distances from rivers. This aligned with the Environment Agency's decommission of 4 of the 6 boreholes used in the Lafare et al. (2016) study to avoid repeated measurement of the same hydrogeological regime. A subset of 11 observation boreholes with high-resolution (15 $\mathrm{min}$ ) data for the study period of 2000-2018 were used in this study; the borehole locations are illustrated in Fig. 1. The groundwater-level data for these borehole locations have undergone correction for barometric effect during data collection by the Environment Agency (S. Gebbett, Environment Agency, personal communication, 2021). The groundwater-level data were converted to daily average groundwater level and used to extend the dataset of Lafare et al. (2016), which spanned 2000-2012. Geographical, geological, and hydrogeological information were gathered for each borehole location. 
To investigate the impact of meteorological heterogeneity, distributed monthly average precipitation and actual evaporation data were obtained from the ERA5-LAND dataset (Muñoz Sabater 2019), which provides distributed meteorological data at a 9-km-grid scale. Sampling point meteorological data from coarse distributed datasets can create bias within the analysis; therefore, additional higher-resolution (1-km-grid) distributed daily estimated rainfall and potential evaporation data for the Eden Catchment were obtained from the gridded estimates of monthly areal rainfall (CEH-GEAR; Tanguy et al. 2019). The higher-

resolution data were used to perform a sensitivity analysis of meteorological data at borehole locations. Distributed meteorological datasets, ERA5-Land (Muñoz Sabater 2019) and CEH-GEAR (Tanguy et al. 2019), were sampled at observation borehole locations to create meteorological time series datasets of rainfall and actual evaporation from the ERA5-Land dataset, and rainfall and potential evaporation from the CEH-GEAR dataset over the period of 01/01/2000-31/12/2017. Aquifer property and borehole $\log$ data were compiled from the aquifer properties database (Allen et al. 1997) and British Geological Survey GeoIndex Onshore database (British Geological Survey 2021), respectively.

\section{Analysis methods}

Firstly, visual categorisation (VC) of the standardised (by subtracting the average and dividing by the standard deviation) groundwater-level datasets was performed. The classification of standardised groundwater hydrographs based on visual inspection introduces subjectivity and expectation. To combat these issues, the $\mathrm{VC}$ was performed without knowledge of which borehole the time series was referring to, to remove any prior knowledge of the researcher, e.g. the geological context of the borehole, or corresponding meteorological data. To quantify the similarities between the different time series, statistical analysis was performed. Statistical approaches considered for this study include cross-correlation/autocorrelation, impulse response function and seasonal trend decomposition by LOESS (STL). STL (Cleveland et al. 1990) analysis was chosen as it requires minimal parameters to decompose time series into component parts—-seasonal, trend, and the remainder, representing interannual, annual and short-term cycles within the time series. The analysis allows the direct comparison of time series from different sources, e.g. groundwater or rainfall. Coupling this technique with detailed evaluation of aquifer properties provides a powerful tool for investigating aquifers that have not previously been studied. The STL method utilises a robust regression that reduces the impact of outlying data points via a locally weighted regression (LOESS) technique. The regression can be linear or a higher order polynomial. For this analysis the linear technique was used, shown in the equation below.

$Y_{t}=T_{t}+S_{t}+R_{t}$

where $Y_{t}$ is the input data at time $t, T_{t}$ is the trend component, $S_{t}$ is the seasonal component and $R_{t}$ is the irregular (remainder) component. Each dataset was processed to meet the requirements of the STL procedure, e.g. uniform interval between data points, uniform periodicity to dataset, and missing values filled using linear interpolation. The STL analysis was applied to the longest continuous groundwater-level time series for each borehole, which varied from 2000 to 2018 for borehole 6, and 2009 to 2018 for borehole 14. Different choices of smoothing parameters were experimented with to extract trend and seasonal components for each hydrograph as recommended by Cleveland et al. (1990). Following the methodology of Lafare et al. (2016), the results of the STL analysis were investigated using the ratio of the variance of each component to the variance of the original time series (Eq. 2), over a consistent window in the time series of 9 water years between 01/10/2009 and $30 / 09 / 2018$

Variance ratio $_{\text {component }}=\frac{\text { Variance }_{\text {component }}}{\text { Variance }_{\text {original }}}$

To investigate the impact of meteorological drivers in groundwater-level fluctuations, the rainfall, actual evaporation, effective rainfall (Eq. 3) and cumulative deviation from mean effective rainfall (Eq. 4) were selected for each borehole site. The STL analysis and subsequent component ratios were calculated for the rainfall, actual evaporation, and effective rainfall time series. These ratios act as a measure of the strength of each component on the original time series.

$\mathrm{EF}_{t}=\mathrm{RF}_{t}-\mathrm{AE}_{t}$

where $\mathrm{EF}_{t}$ is the effective rainfall for month $t, \mathrm{RF}_{t}$ is the rainfall total for month $t, \mathrm{AE}_{t}$ is the actual evaporation during month $t$.

$\operatorname{cumEF}_{t}=\sum_{t=1}^{n}\left(\mathrm{EF}_{t}-\mu_{\mathrm{t}}\right)$

where cumEF$F_{t}$ is the cumulative deviation from the mean monthly effective rainfall, $\mathrm{EF}_{t}$ is the effective rainfall for month $t$, and $\mu_{t}$ is the mean effective rainfall for month $t$ calculated from the period 2000-2018.

The impact of sources of heterogeneity were investigated by interpreting the STL results in combination with aquifer property data obtained from Allen et al. (1997) and geological drill logs from the British Geological Survey GeoIndex Onshore database (British Geological Survey 2021). 
Previous aquifer property research shows that the Penrith Sandstone has higher transmissivity than the St Bees Sandstone (Allen et al. 1997; Younger and Milne 1997). Pump test results show greater hydraulic conductivity estimates than laboratory results (Allen et al. 1997). Within the Penrith Sandstone, Lovelock et al. (1975) show that, in general, there is good agreement between sample and packer pump test aquifer property results. However, these data do not provide insight into vertical heterogeneity and their scarcity means that it is difficult to identify regional trends in aquifer properties. As such, this study investigated heterogeneity at the local scale using British Geological Survey (BGS) laboratory results to interpret the hydrograph and STL results. This method is only applied for the Permian Penrith Sandstone aquifer as there are insufficient aquifer property data to perform this analysis for the Triassic St Bees Sandstone.

\section{Results}

\section{Visual classification of groundwater hydrograph results}

Groundwater hydrographs within the Eden Valley exhibit a range of profiles that vary in shape and amplitude. To better compare the hydrographs, the standardised groundwater-level measurements were visually classified into three groups; the spatial distribution of these categories is shown in Fig. 2, and the groundwater hydrographs are shown in Fig. 3. These are summarised as:

Category A. Groundwater level that exhibits strong seasonal fluctuations, with flashy fluctuations mainly observed during the recharge season. This collection of

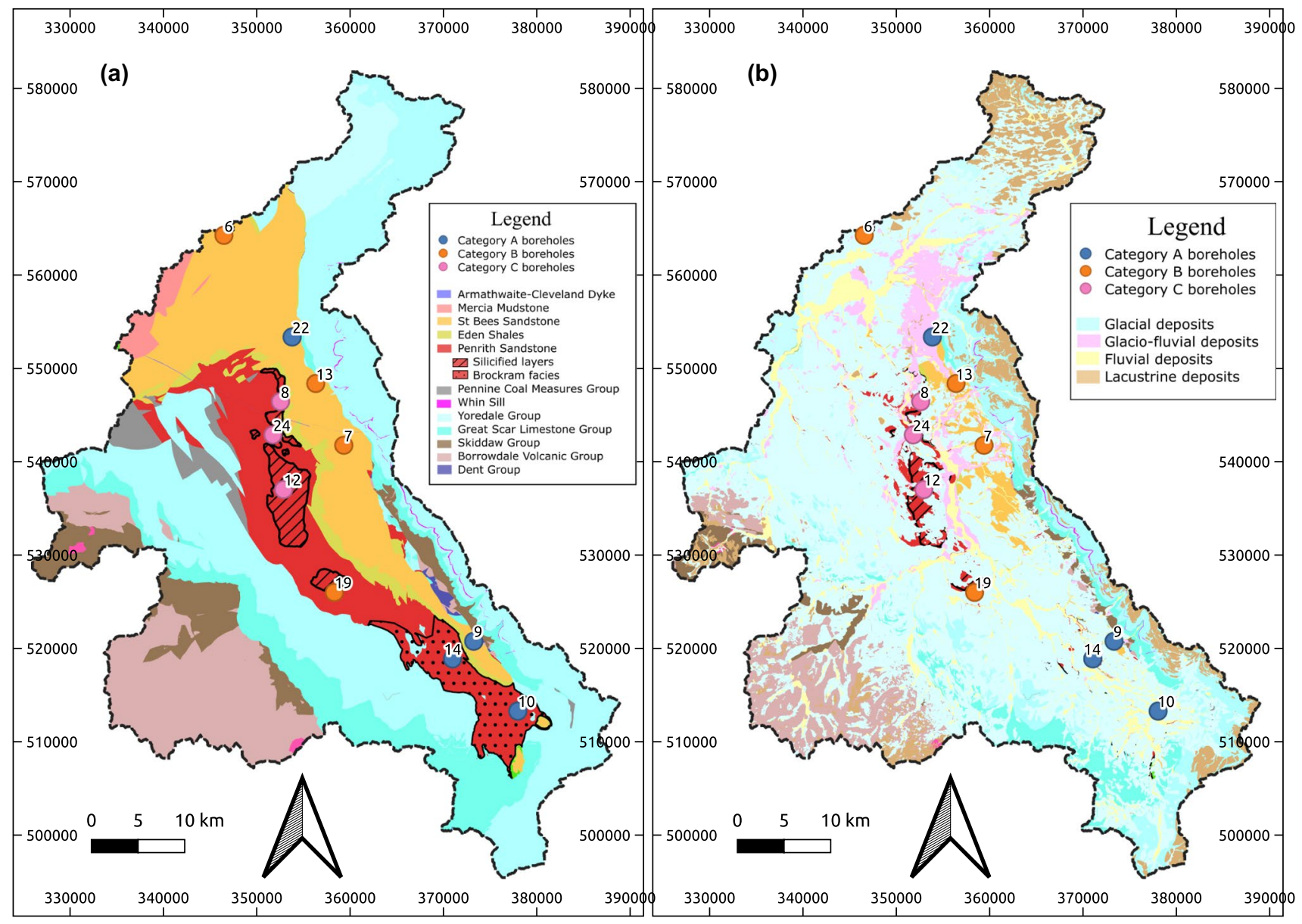

Fig. 2 Simplified geologic maps of the Permo-Triassic Sandstone aquifers of the Eden Valley: a Bedrock geology map that displays regions that contain large-scale heterogeneous features, specifically within the Penrith Sandstone. b Quaternary deposit map. Observation borehole hydrograph classification denoted by categories A (blue), B (orange) and $\mathrm{C}$ (pink). For consistency, borehole numbering follows that of Lafare et al. (2016). (C) UKRI 2021, as represented by BGS and contains Ordnance Survey data (C) Crown copyright and database right 2021 
Category A

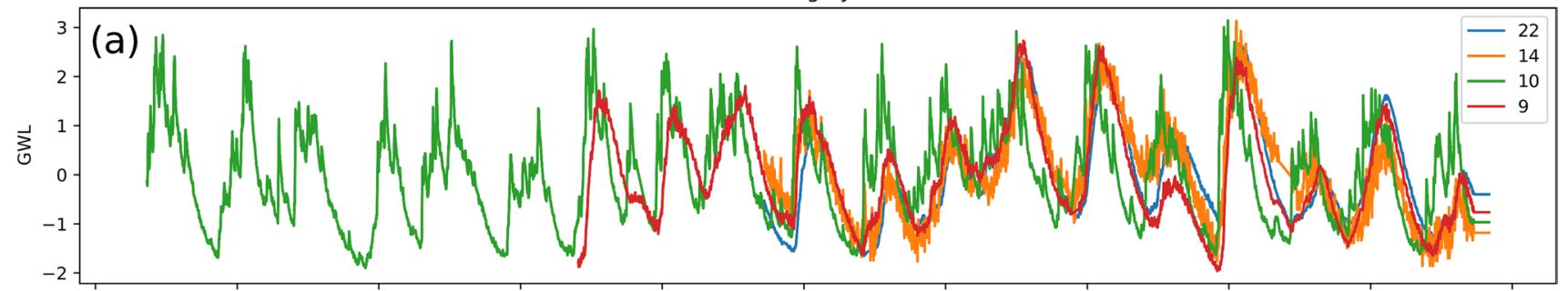

Category B

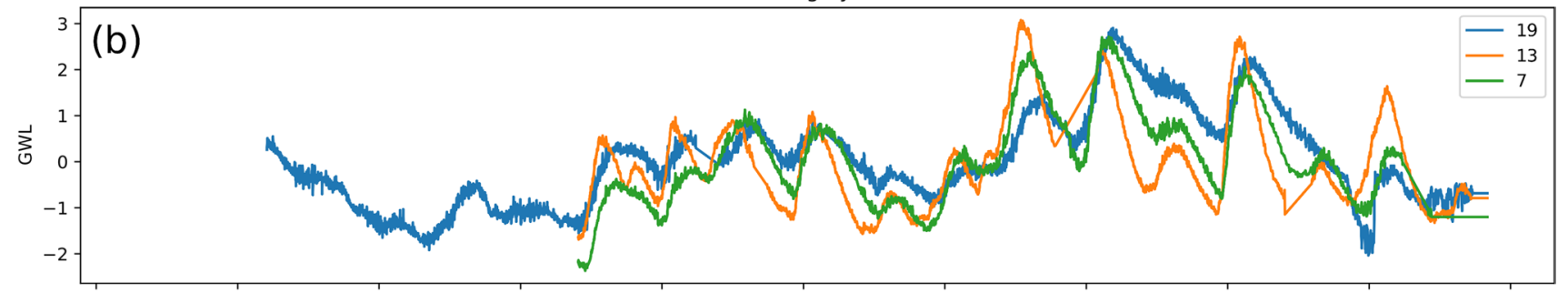

Category C

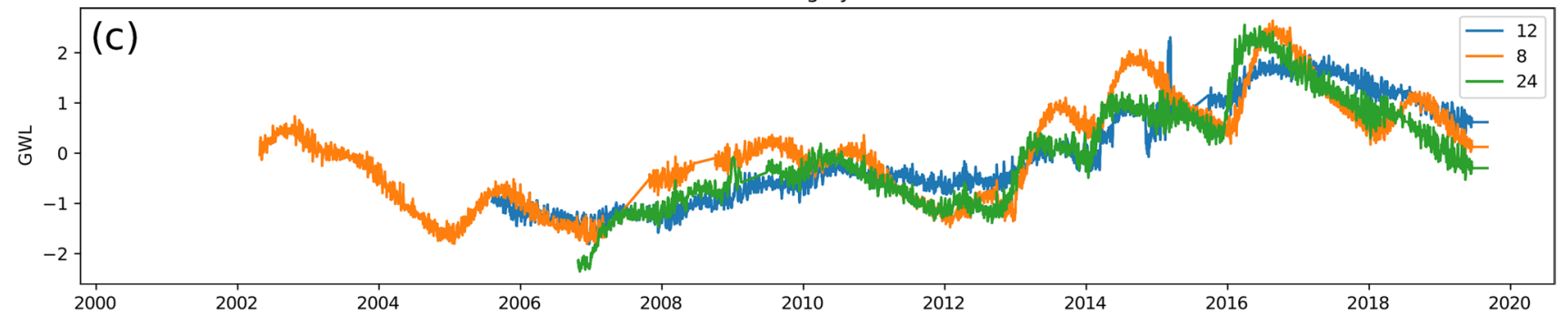

Fig. 3 Standardised and visually categorised groundwater-level time series for each observation borehole in the Eden Valley, Cumbria. a Category A = flashy groundwater hydrograph; b Category B = seasonally dominated groundwater hydrograph, with periods of stable

boreholes contains multiple boreholes that are located adjacent to rivers in the catchment (e.g. Great Musgrave). Category B. Groundwater-level time series that exhibit strong seasonal fluctuations, with a reduced amplitude to flashy changes in groundwater level. These time series also exhibit stands of multiple years during which the groundwater level is relatively stationary with transition periods between these stands. Spatially, these boreholes populate the central region of the Penrith Sandstone and northern extent of the St Bees Sandstone.

Category $C$. Groundwater-level time series that exhibit fluctuations with very small changes over short time periods ( $<30$ days). These time series appear to be dominated by long-term trends with little influence from seasonal and or shorter time-scale responses. These boreholes are all located in the Ingram (1978) mapped silicified region of the Penrith Sandstone.

These borehole categories have been further investigated using the STL analysis (Cleveland et al. 1990) in order to further characterise the hydrograph categories statistically. fluctuations and transitional changes in groundwater levels; c Category $\mathrm{C}=$ smooth groundwater hydrograph, long-term trend dominated time series, with large amplitude seasonal time series

\section{STL results}

The results of the STL decomposition of the groundwater hydrographs, as shown in Fig. 4, support the categorisation from the visual comparison analysis and illustrate the variation within each category. Category A hydrographs exhibit the strongest remainder component over the time series, with a moderate seasonal component of almost uniform amplitude. The trend signal comprises the smallest component of category A decomposition results and remains relatively stable over the time series. Whereas, the trend component for category B boreholes exhibit periods of stability punctuated by transitional periods, most notably during the winter 2011-2012. Category B hydrographs show a low-amplitude uniform seasonal component during the early- to mid-time series (2000-2013), followed by a period of increased seasonal fluctuation during the late time series (2013-2018). The same pattern is also observed in the remainder component. The periods of stability and transition observed in the groundwater hydrograph visual classification stage 

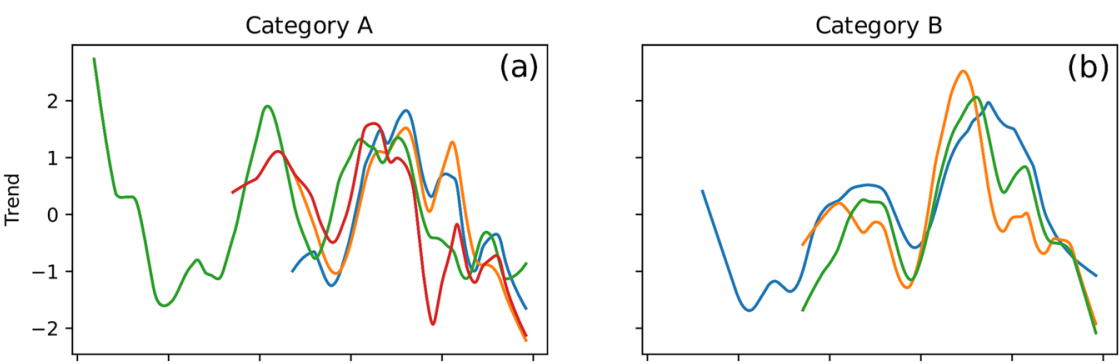

Category C
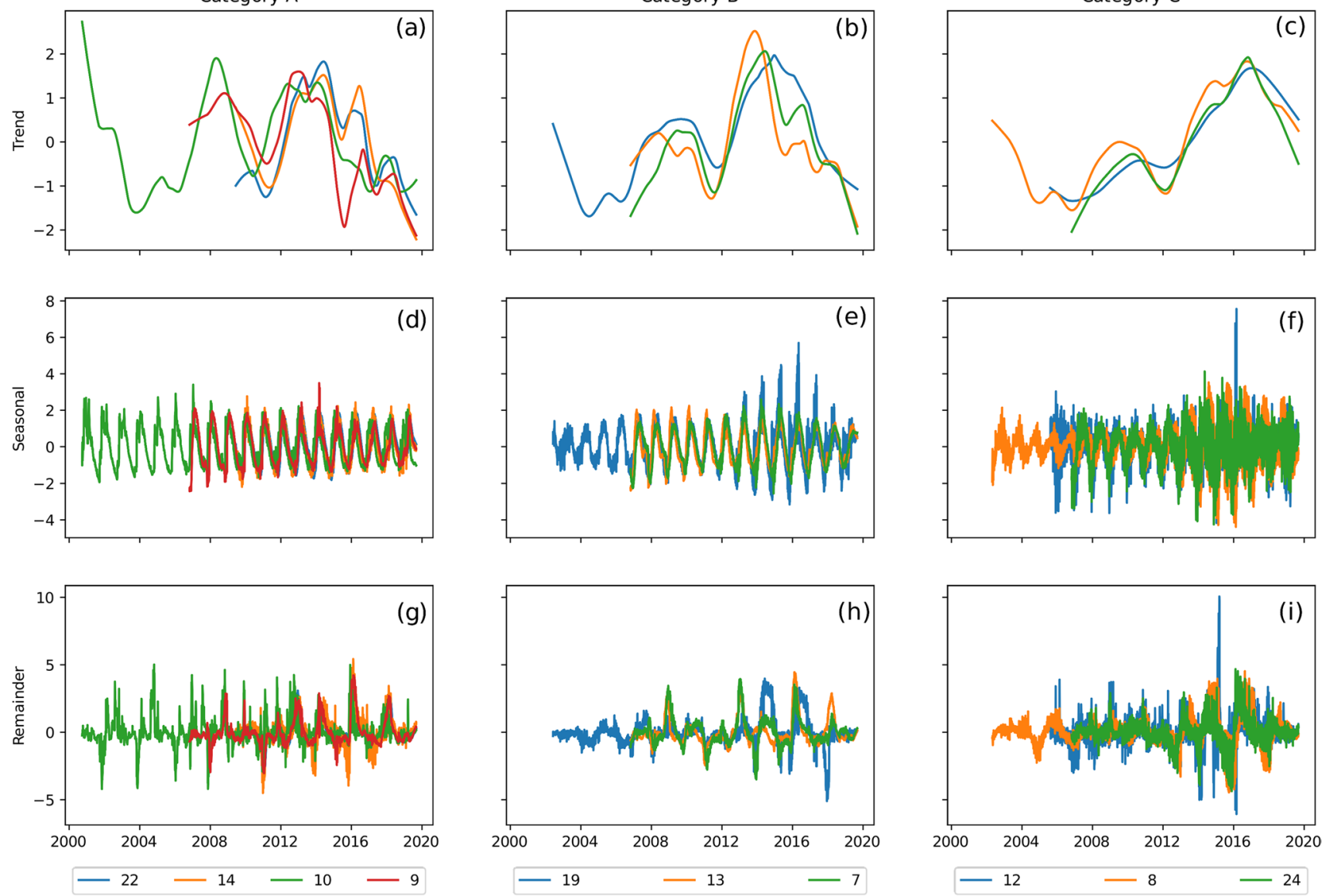

Fig. 4 a-i Standardised STL results for the categorised groundwater-level time series. The data have been subplotted by the STL component (rows); top row, trend component; middle row, seasonal component; and bottom row, remainder component, and VC of bore- holes (columns); first column is category A, second column is category B, and third column is category $\mathrm{C}$. Each borehole time series is displayed with a different colour within the columns, the legend for which is included at the bottom of the column are clearly visible in the trend signal, e.g. 2004-2012 stable period followed by 2012-2016 transitional period. Category $\mathrm{C}$ hydrographs exhibit a consistently increasing trend component between 2006 and 2016, followed by a decreasing trend component to the end of the time series. The seasonal component exhibits a larger amplitude than either category A or B, with the largest amplitude fluctuations occurring between 2013 and 2017. The remainder component follows those of category B; however, the category $\mathrm{C}$ remainder signal has a slightly larger amplitude.

The STL analysis has attributed rapid groundwater-level fluctuations during regional flooding associated with Storm Desmond (Dec 2015) to different decomposition components. This is observed in the large seasonal peak in category $\mathrm{C}$ and a smaller amplitude in category B boreholes (Fig. 4), whereas, the peak is observed in the remainder signal of category A boreholes.

\section{Meteorological data}

To evaluate the potential meteorological source of the different groundwater hydrograph categories (A, B and C), each meteorological dataset_rainfall, actual evaporation, effective rainfall, cumulative deviation from mean monthly effective rainfall - was plotted by borehole location and visual categories A, B and C (Fig. 5). Inspection of the data clearly shows that while the Eden Valley exhibits a heterogeneous distribution of rainfall at the catchment scale, the meteorological time series exhibit spatial homogeneity. The decomposition component variance ratios were utilised to tease out the meteorological impact on the groundwater time series.

\section{Variance ratio analysis}

Following the methodology of Lafare et al. (2016) the ratios of the decomposition components to the original 

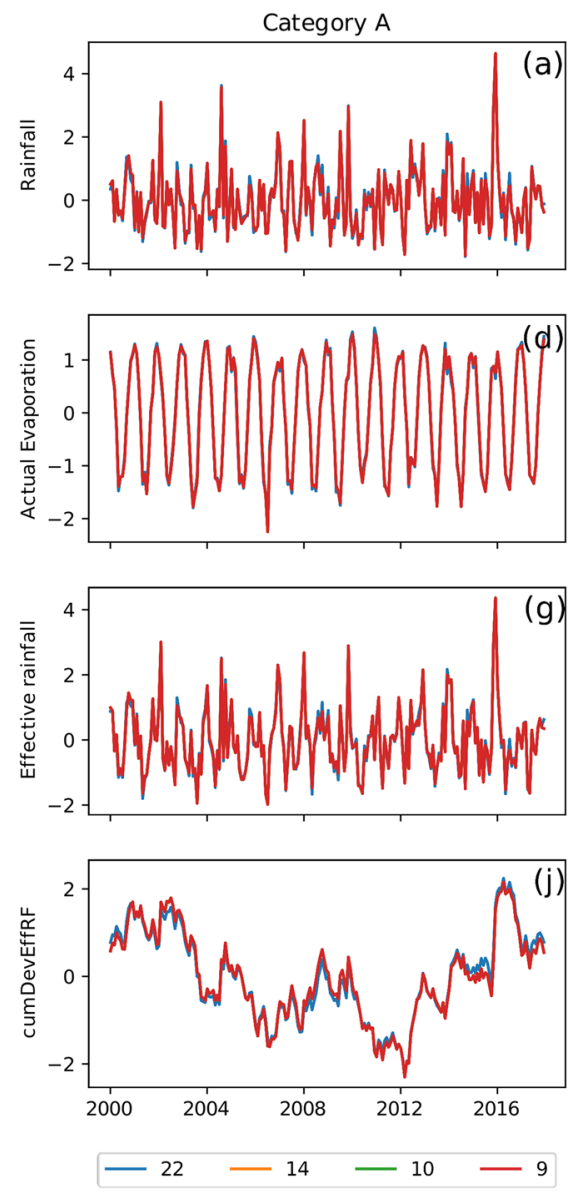

Fig. 5 a-l Meteorological data for each borehole location grouped by visual categorisation of groundwater hydrographs (columns). First row, monthly rainfall; second row, monthly actual evaporation (AE); third row, monthly effective rainfall; and bottom row, cumulative
Category B
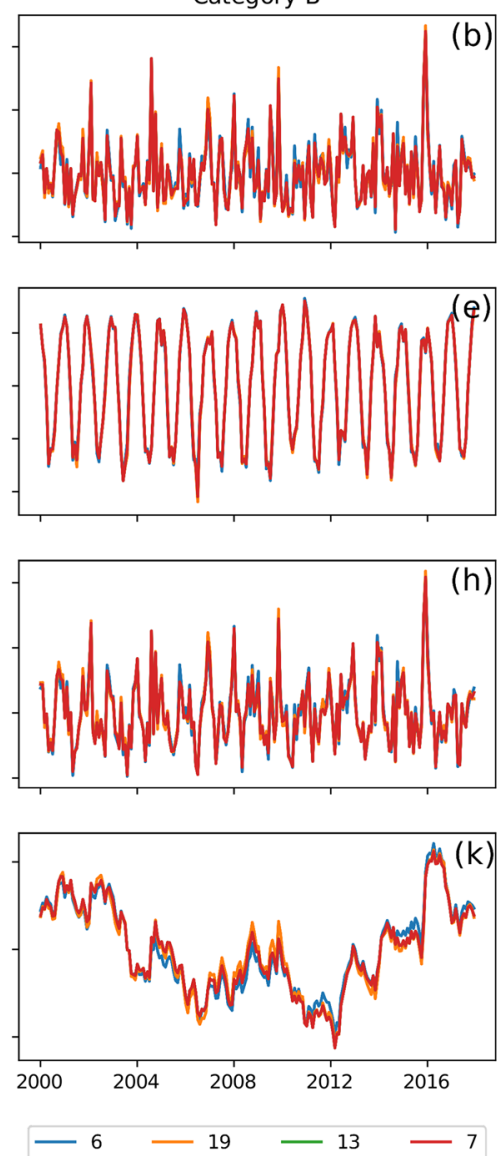

Category C
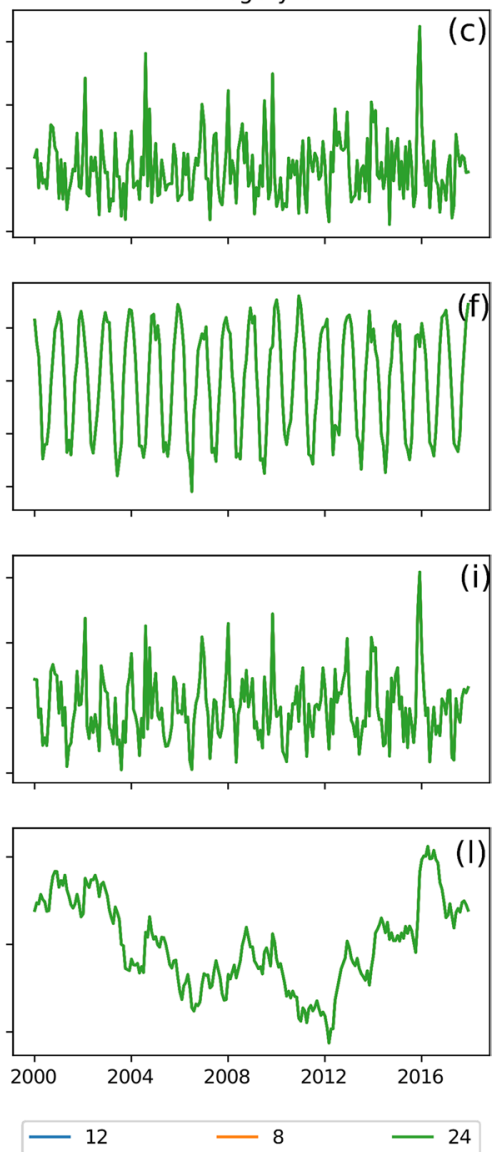

deviation from mean monthly effective rainfall. Each borehole time series is displayed with a different colour within the columns, the legend for which is included at the bottom of the column

signal are summarised in Table 1 . The same ratios were calculated for the rainfall, actual evaporation, and effective rainfall time series at each borehole location, shown in Fig. 6 and summarised in Appendix 1. The ratio results show that the rainfall decomposition is dominated by the remainder component, with moderate relative variance attributed to seasonal and very little attributed to trend, whereas, the actual evaporation decomposition is dominated by seasonal with minor remainder or trend components. When these time series are combined in calculating effective rainfall, the resulting time series decomposes into approximately equal seasonal and remainder components with minor variance attributed to the trend component. Throughout the meteorological driver variance analysis, all the visual classification (VC) borehole categories cluster together, with minor spread observed in the variance ratios for seasonal and remainder signals. By comparison, the groundwater time series exhibits much greater variance range across all

decomposition components and the VC borehole categories cluster into distinct zones. This implies that the variance spread observed in the groundwater time series decomposition is not generated by meteorological drivers.

The groundwater variance ratios show that each visual category of groundwater time series exhibits distinct decomposition component ratio strength. Category A boreholes exhibit the largest spread in the relative STL component ratio. They are dominated by seasonal (range from 0.35 to 0.65 ) and residual (range from 0.3 to 0.45 ) components. Category B boreholes are dominated by the trend component, which ranges from 0.4 to 0.65 , with equal seasonal (less than 0.2) and residual (between 0.18 and 0.42 ) ratio strength, whereas, category $\mathrm{C}$ boreholes are tightly clustered and are almost entirely comprised of the trend ratio (greater than 0.78 ), with minimal residual (less than 0.2) and even smaller seasonal (less than $0.1)$ components. These differences enable one to define 


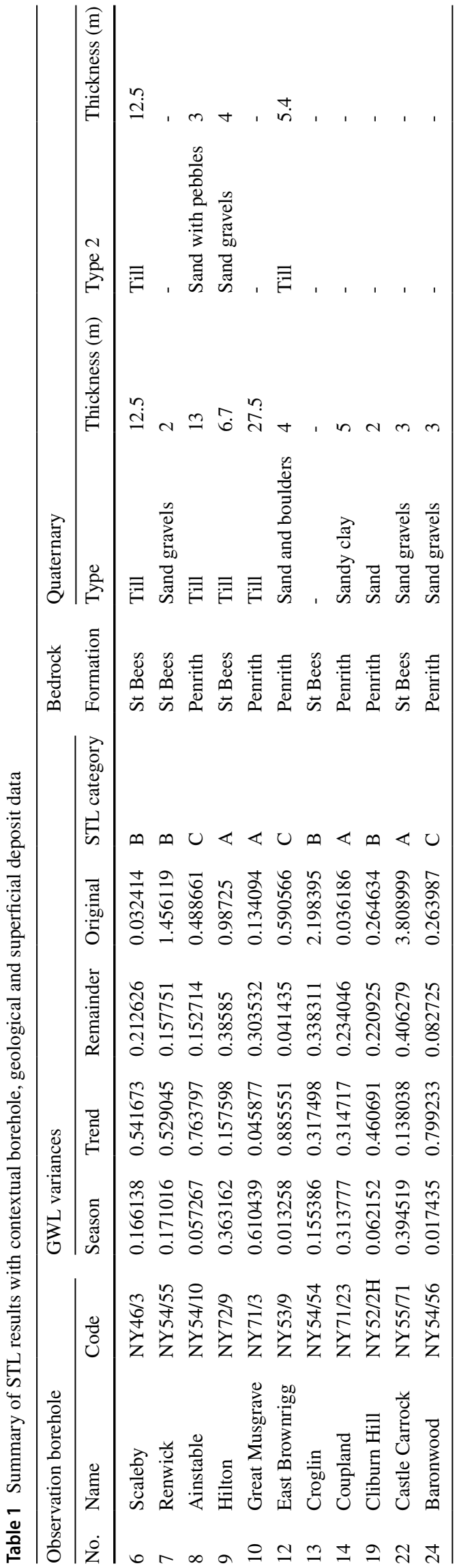

hydrogeological regime for these groups of boreholes. The different groundwater-level responses are thought to be due to variation in superficial cover or vertical heterogeneity.

\section{Aquifer properties}

Analysis of aquifer property data available for the area showed extensive variation of porosity and permeability with depth. Representative borehole data for each VC group are presented in Fig. 7 (VC A), Fig. 8 (VC B) and Fig. 9 (VC C). Category A boreholes are in the Brockram facies of the Penrith Sandstone and the St Bees Sandstone (as shown in Fig. 2). Within the Brockram facies of the Penrith Sandstone, permeability is very low-less than 1,500 mDarcy $(\mathrm{mD})$; see Fig. 7-especially within the breccia flows. Minor anisotropy is observed within category A boreholes, while porosity varies between 10 and $27 \%$ with the lowest porosity measurements taken from the breccia facies. Category A boreholes constantly exhibit water-table fluctuations within the superficial deposits. In Fig. 7, the superficial deposits comprise thick (24 m) glacial till; however, other boreholes include $5 \mathrm{~m}$ of sandy clay and $3 \mathrm{~m}$ of glacio-fluvial deposits. Category B boreholes, in the Penrith Sandstone, exhibit a complex layering of interbedded hard silicified and competent sandstone, which comprise friable beds and coarse beds of sandstone. These layers have distinct hydrogeologic properties, with isotropic low-permeability in the hard sandstone; moderately anisotropic variable permeability within the friable sandstone; and anisotropic high-permeability within the competent sandstone. Porosity varies from 10 to $32 \%$, with the highest and lowest porosity measurements observed in the friable layers and competent hard layers, respectively. Consistently for category B boreholes, the groundwater-level fluctuates in the upper aquifer levels just below the superficial deposits. Boreholes in this category are also associated with thin or high-permeability superficial deposits such as sands and gravels; the exception to this is borehole 6, which intersects 11-m-thick till deposits. Category $\mathrm{C}$ boreholes all exhibit isotropic lowpermeability and low-porosity within the upper $\sim 40 \mathrm{~m}$ of the Penrith Sandstone, which is associated silicified beds (illustrated in Fig. 9). Below this, the permeability and porosity increase to approximately $2,500 \mathrm{mD}$ and $25-30 \%$ respectively. Within this section, anisotropy is more pronounced but lessens with depth. All category $\mathrm{C}$ boreholes exhibit deep-lying water tables that fluctuate within the high-permeability zone, below the silicified layers. Category $\mathrm{C}$ boreholes occur in locations with superficial deposits that vary from thick glacial till $(10 \mathrm{~m})$ to glacial till $(5.5 \mathrm{~m})$ overlain by sands and gravels $(4 \mathrm{~m}$; shown in Fig. 9) to thin sands and gravels (3 m). 
Fig. 6 Variance ratio data for rainfall (rf), actual evaporation (ae), effective rainfall (effRF), and groundwater level (gwl) time series at each borehole site in the Eden Valley, Cumbria. Visual categories of boreholes denoted by symbol and data source denoted by colour of marker

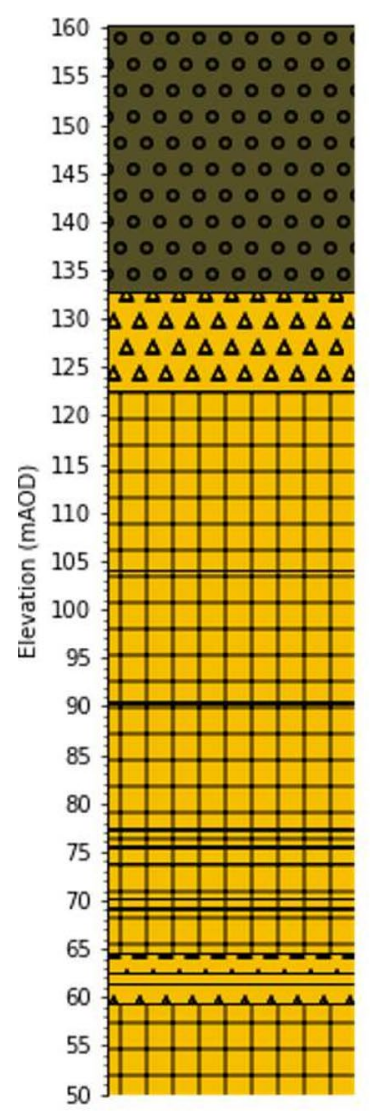

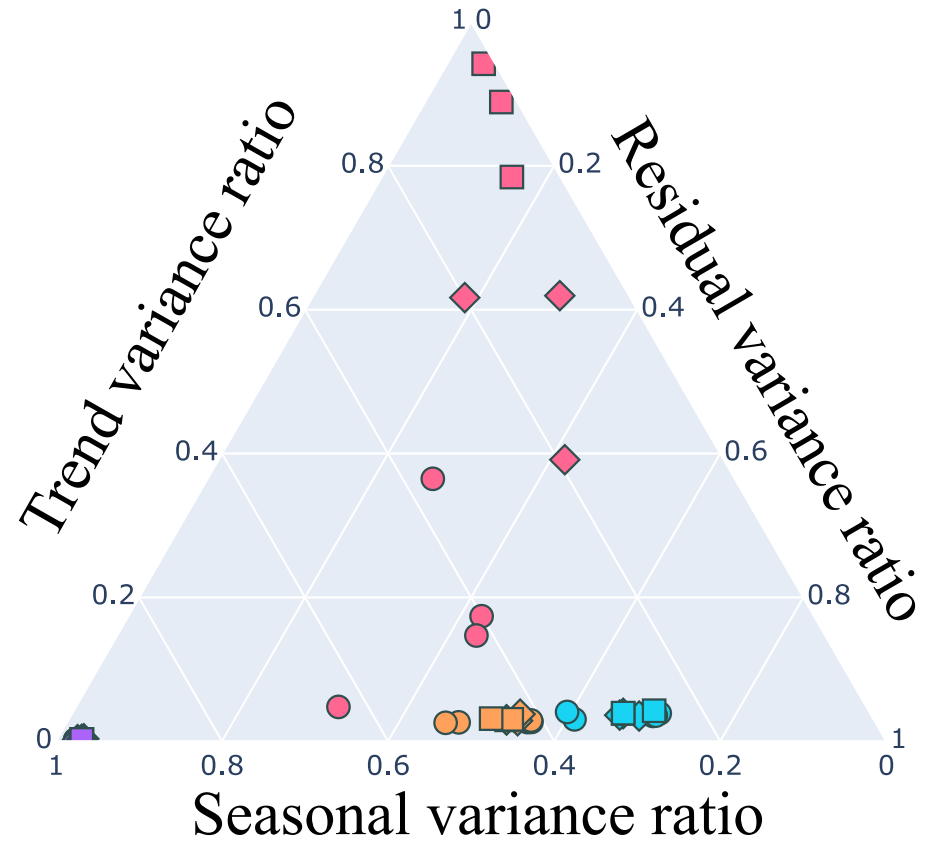

Legend

ae, $A$

$\diamond$ ae, $B$

$\square$ ae, C

$\bigcirc$ effRF, A

$\diamond$ effRF, B

$\square$ effRF, C

rf, $A$

$\diamond r f, B$

$\square \quad r f, C$

gwl, A

$\diamond \mathrm{gwl}, \mathrm{B}$

$\mathrm{gwl}, \mathrm{C}$
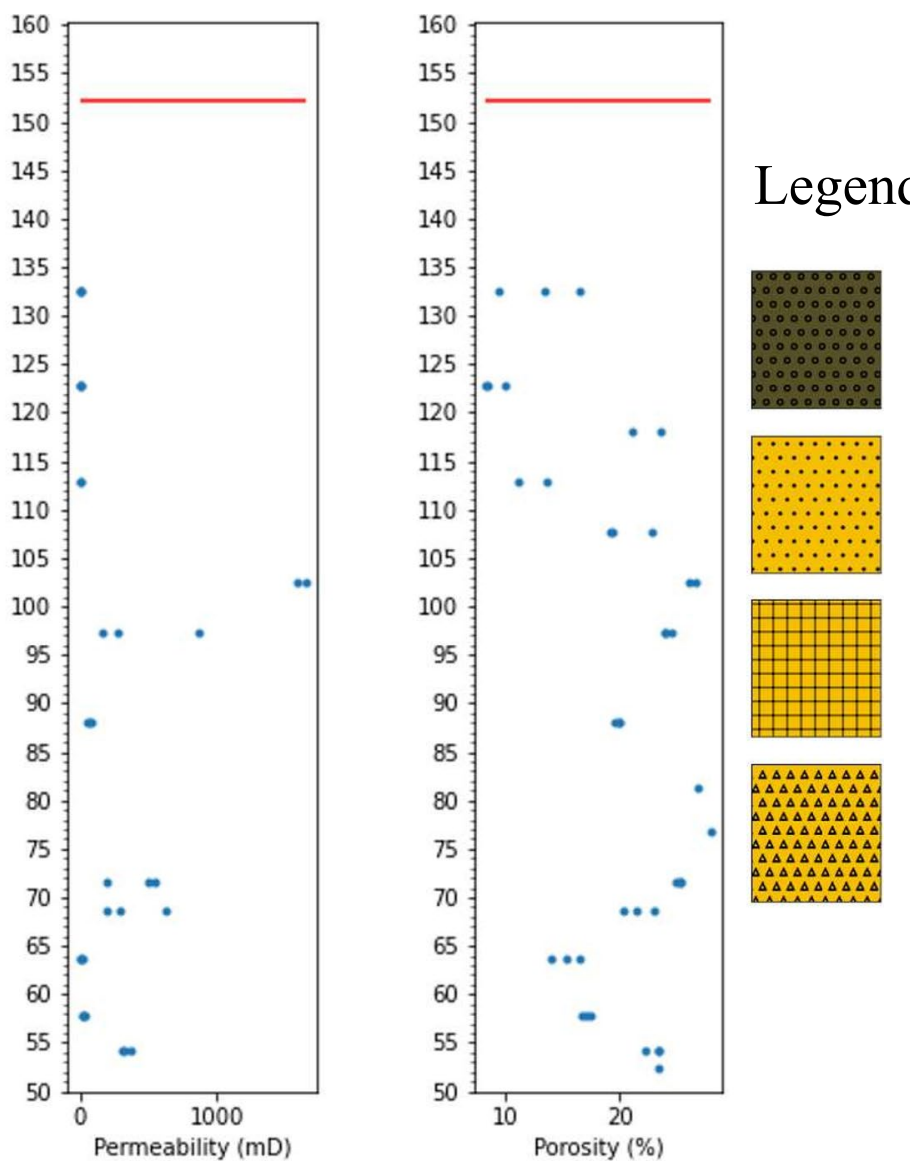

Till, red brown, boulder, sandy

Sandstone, grey green, grains, sandy

Sandstone, red brown, fine to coarse grained, friable

Breccia, fine to coarse, hard, fragments

Fig. 7 Aquifer property data for Great Musgrave observation borehole, typical of category A within the Brockram facies of the Penrith Sandstone. Average groundwater level is denoted by the horizontal red line in both the permeability and porosity plots 
Fig. 8 Aquifer property data for Cliburn Hill observation borehole, typical of category $B$ within the aeolian facies of the Penrith Sandstone. Average groundwater level is denoted by the horizontal red line in both the permeability and porosity plots

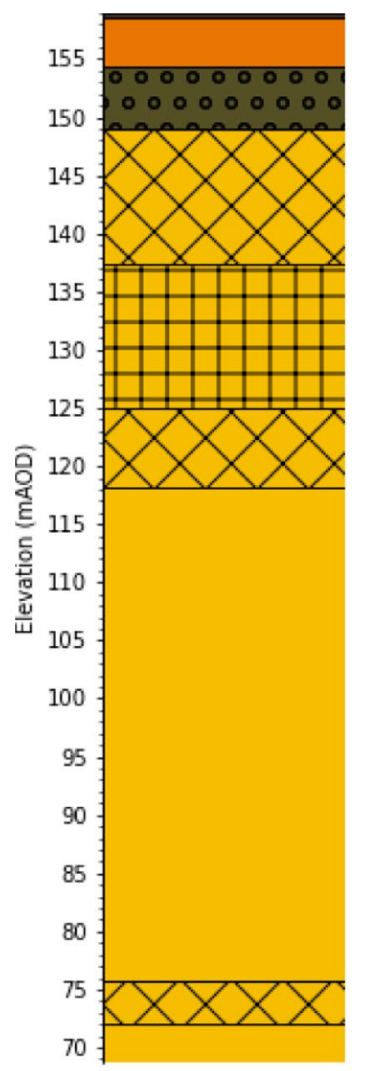

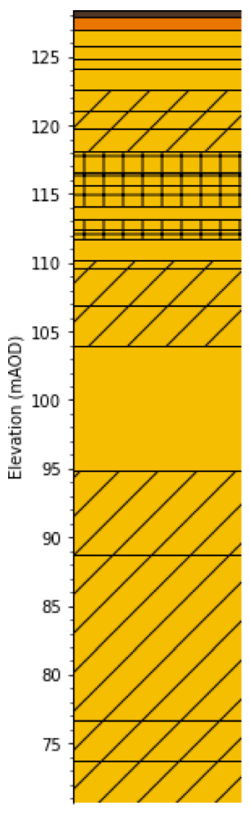
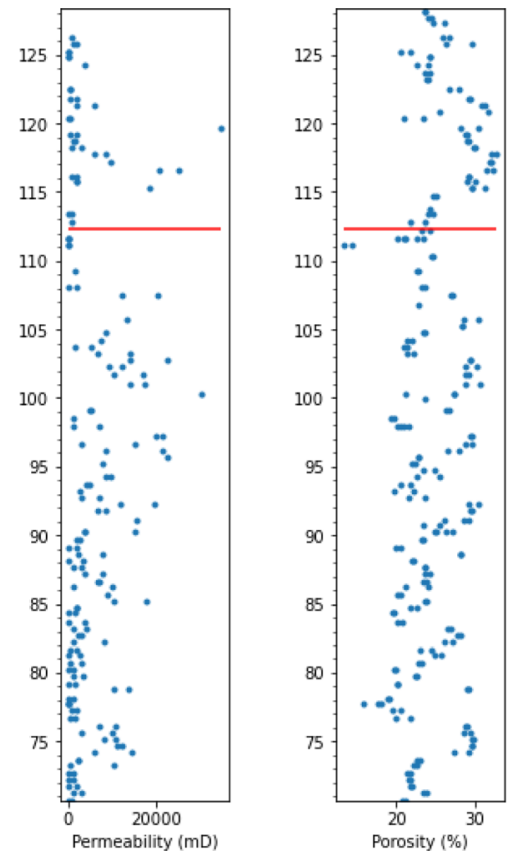

\section{Legend}
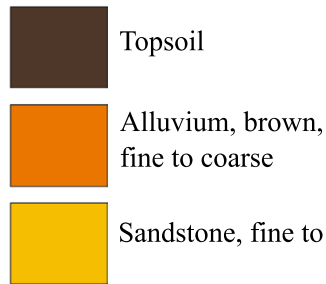

Sandstone, fine to coarse

\#\# Sandstone, red brown, fine to coarse, friable

Sandstone, fine to coarse, hard
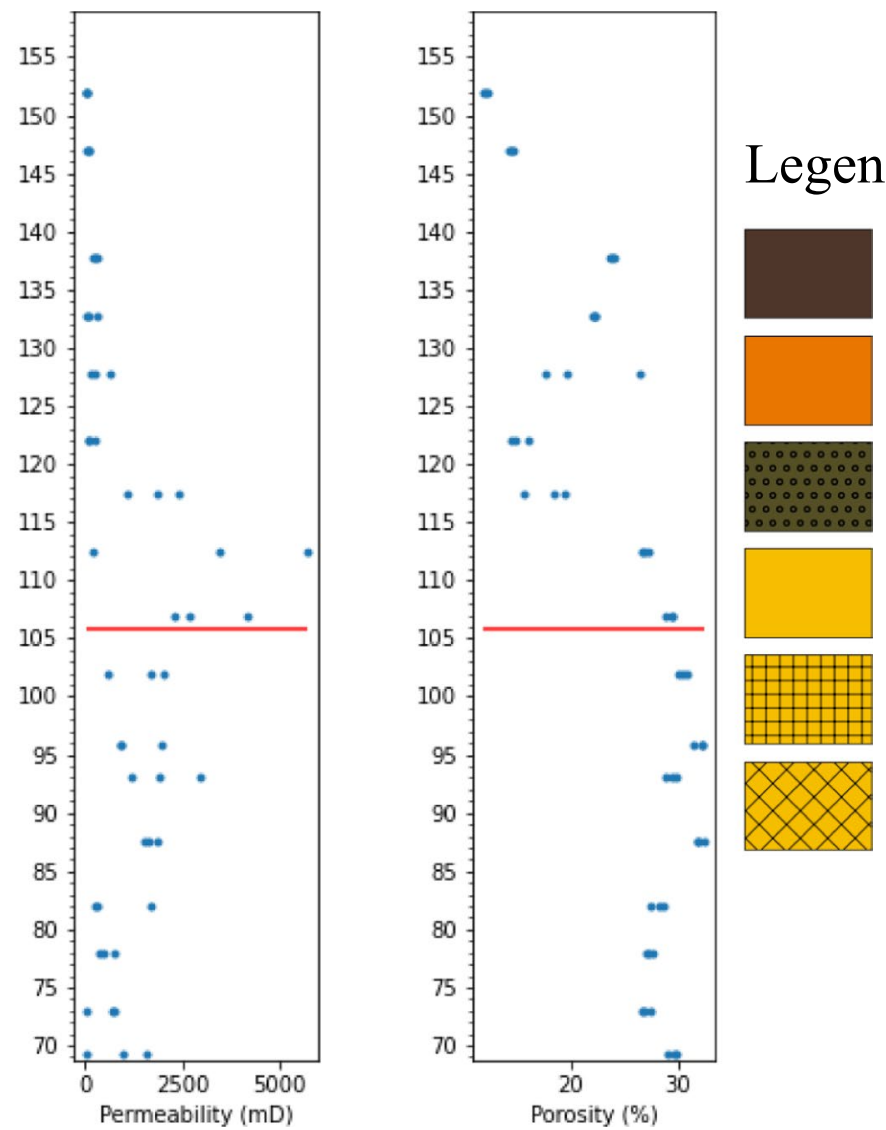

Topsoil

Alluvium, brown, fine to coarse

Till, red brown, sandy

Sandstone, fine to coarse

Sandstone, red brown, fine to coarse, friable Sandstone, fine to coarse, very hard

Fig. 9 Aquifer property data for East Brownrigg observation borehole, typical of category C within the Silicified region of the Penrith Sandstone. Average groundwater level is denoted by the horizontal red line in both the permeability and porosity plots 


\section{Discussion}

In this study, quantitative techniques have been applied to groundwater-level hydrographs with the overarching aim of developing a better understanding of local conceptual hydrological functioning. The use of visual classification utilised the power of human pattern recognition. The application of STL confirmed the differences between and similarities within these hydrograph categories. When plotted spatially (Fig. 2), these categories define distinct regions within the Permo-Triassic sandstone aquifers of the Eden Valley. Each region has a different set of hydrogeological features that combine to produce the groundwater-level time series in response to recharge. The important features controlling groundwater-level response are silicified layers (VC C), followed by high-stand/low-stand variation (VC B), followed by those most heavily influenced by meteorological drivers (VC A).

The category $\mathrm{C}$ hydrogeological region is thought to be strongly influenced by the presence of silicified layers which are of low porosity and permeability and, therefore, restrict vertical flow. Through the review of borehole construction logs in the category $\mathrm{C}$ region, it is apparent that these layers locally confine the sandstone aquifer with reports of water upwelling upon breaking through the bottom of the hard sandstone layers. These layers also create perched aquifers in the overlying strata and superficial deposits, as many water strikes are reported in these logs. This would suggest that the silicified layers locally disconnect the surface-water and groundwater systems, greatly reducing direct recharge. The disconnection of the groundwater system is best illustrated by the variance ratios plotted in Fig. 6, where category $\mathrm{C}$ boreholes are dominated by the trend signal (greater than 0.8 ), the opposite of the meteorological drivers that are dominated by residual and seasonal components (cumulatively 0.9). The hypothesised reduced direct recharge through the silicified layers, proportionally increases the component of indirect lateral recharge into high-conductivity sandstone below the silicified layers. This represents a new conceptualisation for recharge processes in this region of the aquifer; however, this cannot be explored through the evaluation of groundwater-level time series due to the low spatial density of observational boreholes in the Permo-Triassic Sandstone aquifers of the Eden Catchment. Previous work has hypothesised that high-recharge zones are related to windows in the superficial deposits (Butcher et al. 2006).

The category B hydrogeological region exhibits periods of stable and transient groundwater-level fluctuations which coincide with similar features observed in the cumulative deviation from mean monthly rainfall (Fig. 5), suggesting that these may be of meteorological origin. This connection to meteorological drivers, combined with the relatively thin, higher-permeability superficial deposits that these boreholes intersect, support this hypothesis. Previous research has shown that direct recharge in the Eden Valley preferentially occurs through fractures in and windows through superficial deposits (Butcher et al. 2006). The relative higher permeability of the superficial deposits observed in category B boreholes supports the hypothesis that this category is associated with the presence of preferential recharge zones. Based on aquifer property data and the proximity of the water table to layered heterogeneity within the aquifer, category B boreholes are likely to exhibit nonlinear changes in groundwater level, which could be a contributing factor to the large amplitude fluctuations observed in the seasonal components.

The category A hydrogeological region appears to be the most similar to the meteorological drivers, based on the variance ratio analysis (Fig. 6), with dominant seasonal and remainder, and only moderate trend components. This coupled with the shallow water table, neutral trend signal and proximity to river channels supports the hypothesis that these boreholes are most closely connected to the surface-water system. The aquifer properties for this region, Brockram facies Penrith Sandstone and St Bees Sandstone proximal to the Pennine Fault System, are typically of lowmoderate porosity and low-moderate permeability, with fracture flow the dominant groundwater flow mechanism (Younger and Milne 1997). The low porosity but relatively high transmissivity exaggerates the flashy nature of the groundwater hydrographs and represents a groundwater regime not typically associated with Permo-Triassic sandstone aquifers.

Boreholes 14 and 13 in categories A and B, respectively, are outliers from their respective category clusters and both occupy component ratio space between the two category clusters. These observations suggests that these boreholes are intermediates between the two categories, A and B. Borehole 14, summarised in Table 1, has a shallow water table that fluctuates in a shallow sandy clay Quaternary deposit that overlies the Brockram facies of the Penrith Sandstone. It is hypothesised that the stronger trend component is due to the northern region of the mapped Brockram facies containing proportionally less of the breccia flow deposits, which would increase matrix porosity and therefore, storage within the aquifer. Unfortunately, this hypothesis cannot be supported by geological observations from the borehole logs as the Coupland borehole (No. 14) is documented as hard sandstone with no comment on the composition or depositional textures. Whereas, borehole 13 exhibits an increased residual component and reduced trend strength compared to the other category B boreholes. 
This borehole is in the northern region of the St Bees Sandstone within a Quaternary window (Fig. 2) with a 30-m-deep water table (Table 1). It is hypothesised that the orographic rainfall and adjacent Carboniferous strata to the east of the Pennine Fault System generates a flashy response to rainfall events, as seen in the Limestone headwaters in the southern Eden Catchment. Combined with the potential preferential flow pathway along the Pennine Fault System, this borehole may be an example of a deep water table that is well connected to the surface-water system. In both cases, these boreholes represent an intermediate step between the distinct categories and may support a gradational spatial transition between the two hydrogeological regimes.

Comparing the different meteorological drivers shows that there is limited variation between each borehole location. This is attributed to the observation boreholes being located along the axial trace of the valley, which is in the lower rainfall orographic effect of the Lake District to the west and Pennines to the east. These findings suggest that variations observed in the groundwater time series are unlikely to be the product of meteorological drivers. The results of the variance analysis indicate that the meteorological drivers are unable to generate the variance observed in the groundwater time series, suggesting that other hydrological processes involved in recharge and discharge from the aquifers are responsible for the spread in the decomposed components of the groundwater-level hydrographs.

Previous research has evaluated groundwater hydrograph analysis against factors such as distance from rivers, depth to water table, and aquifer properties between lithological units (Lafare et al. 2021). They conclude that there are four hydrogeologic zones: (1) St Bees Sandstone, (2) Brockram, (3) silicified Penrith Sandstone and (4) central Penrith Sandstone, which is heavily influenced by interaction with rivers. These zones broadly align with the categories proposed in this research, with key differences in the St Bees Sandstone, which this research suggests is more heterogeneous than proposed by Lafare et al. (2021), and zone 4 of Lafare et al. (2021) which this work interprets to be a continuum between the agreed upon silicified Penrith Sandstone and Brockram zones, category A and $\mathrm{C}$. The reasons for the differences in categorisation of the central Penrith Sandstone is that this work excluded boreholes near rivers, many of which are in the central Penrith Sandstone region (Fig. 1). While this represents an important component of impacted fluctuation, the current study highlights that vertical variations in aquifer properties and composition of superficial deposits have a significant impact on fluctuation and should therefore be considered alongside distance from river systems. The heterogeneity of the St Bees Sandstone aquifer is difficult to comment on as aquifer properties have not been extensively investigated in the Eden Valley. Research into analogous deposits, the St Bees Sandstone at St Bees Head Cumbria, propose that aquifer quality within fluvial deposits improves with distance from the sedimentary source (Medici et al. 2019). Within the St Bees Sandstone of the Eden Valley, this increased quality would be exhibited in a northward direction, which is confirmed by Allen et al. (1997) who state that permeability is higher in the north than the south and show that porosity is on average 27 and $16 \%$, respectively, within the northern and southern regions.

Pumping test data are scarce and poorly distributed especially within the St Bees Sandstone; thus, this research evaluates aquifer properties from core sample measurements. Looking at the aquifer properties with depth enables the identification of regions in which nonlinear changes in groundwater level may occur.

The methods employed in this research have some limitations that must be acknowledged. Firstly, the meteorological data are a distributed dataset on a $9-\mathrm{km}$ grid. This means that due to their proximity, observation boreholes within category $\mathrm{C}$ have been allocated the same meteorological dataset, illustrated in Fig. 5; therefore, these data fail to account for the variation likely to occur between these sites. An investigation into the meteorological heterogeneity shows that the rainfall is relatively homogeneous over the Permo-Triassic Sandstone aquifer outcrop where observation boreholes are located. Double-mass plots have been used to compare the two meteorological data sources. These plots demonstrate that there is variation between the two rainfall data sources; however, this variation is consistent throughout the time series. A sensitivity analysis has been conducted using higherresolution rainfall data (CEH-GEAR) that is produced at a 1-km grid scale and shows that the impact of distributed rainfall resolution is minimal. The results of the sensitivity analysis are included in Appendix 2 Fig. 10, 11, 12 and 13 , where Fig. 6 has been reproduced using the higher-resolution rainfall data. Given the minimal impact of meteorological data resolution, the ERA5 data source is preferred for this investigation as it is the source for the actual evaporation data, which are not available as part of the CEH-GEAR dataset.

Secondly, the current analyses are constrained due to the relatively limited number of observation boreholes and the lack of hydrogeological property data for the St Bees Sandstone to carry out analyses at the borehole scale. This increases the uncertainty when defining boundaries between categories of distinct hydrogeological regions within Penrith and the St. Bees sandstone aquifers. To address this, future research should explore different hydrogeological zones using groundwater modelling to examine the boundaries between these zones and reduce uncertainty. The use of 
analogous lithologies (e.g. St Bees Sandstone at St Bees Head, Cumbria) and geostatistical methods to fill gaps in aquifer property data, should be explored.

\section{Conclusions}

This research provides a simple method of using readily available data (i.e. groundwater level, borehole logs and aquifer properties with depth) to identify three distinct hydrogeological zones within the Permo-Triassic sandstone aquifers of the Eden Catchment, Cumbria. This work represents an intermediate step that constrains conceptual understanding of the hydrogeological cycle, to be taken before the development of a distributed groundwater model. The impact of geological heterogeneity on the groundwater system had been previously underestimated-for example, the aeolian facies of the Penrith Sandstone has previously been hypothesised as homogeneous (Younger and Milne 1997), though the heterogeneity presented, e.g. silicified layers impose a strong influence on regional recharge and groundwater flow processes.

This work has shown that the variance in groundwater fluctuations is not a product of meteorological drivers, highlighting the complexity of recharge processes in the Eden Catchment. This has implications for future work that should focus on defining the geometry and composition of geological features such as silicified layers and superficial deposits, and confirming the connectivity relationships proposed in this paper using groundwater chemistry. The connectivity between surface-water and groundwater systems is of great importance to the diffuse agricultural contamination within the catchment (Wang et al. 2013).

One of the overriding benefits of this work is that it highlights areas of uncertainty within the hydrogeological cycle in the Eden Catchment. Further work investigating this aquifer system should focus on, firstly, increasing the density of aquifer property data within both Permo-Triassic Sandstone aquifer units, especially the St Bees Sandstone; and secondly, defining the spatial distribution in threedimensions of the silicified region of the Penrith Sandstone. Silicified layers occur throughout the aeolian Penrith Sandstone (Younger and Milne 1997) but region C may represent a distinct hydrogeological regime, where the surface and groundwater are disconnected by thick silicified layers and glacial till deposits.

The use of STL analysis in combination with detailed aquifer property data is a low-impact highly insightful investigative tool. In the future, this method should be applied to large-scale groundwater-level time series to investigate the resolution that it can define within distinct hydrogeological regions.

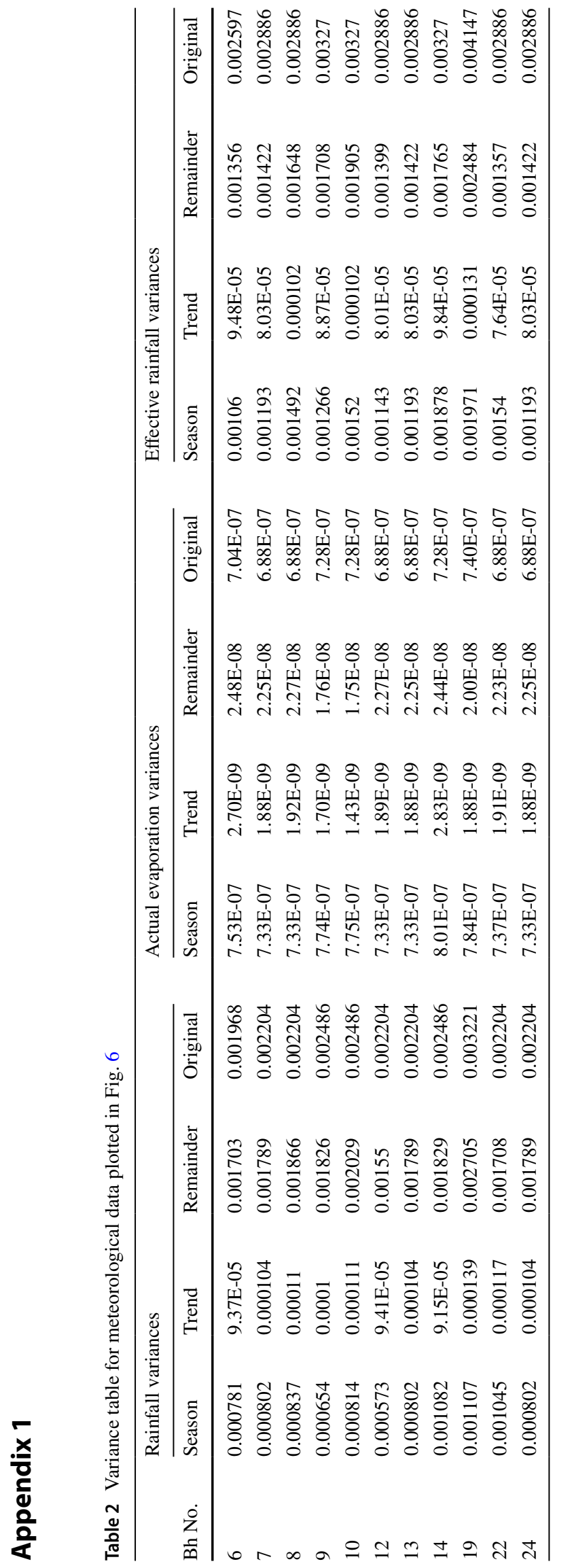




\section{Appendix 2}

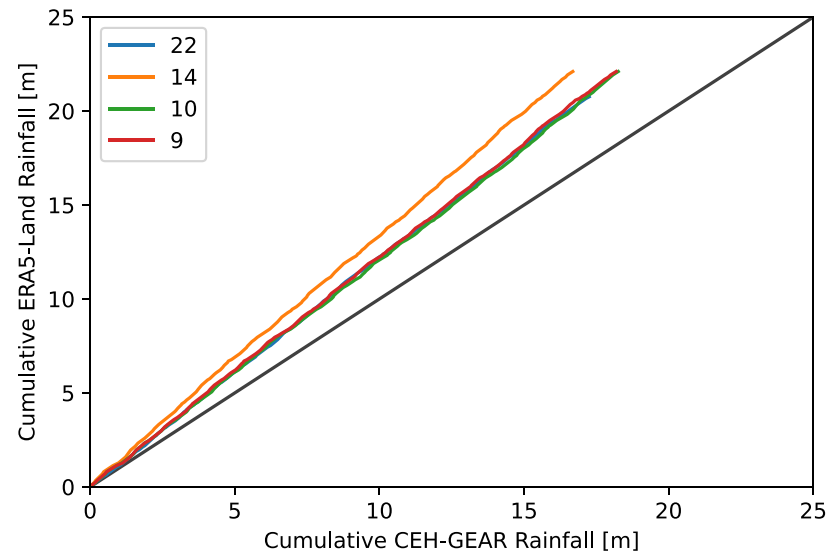

Fig. 10 Double mass plot of ERA5-Land and CEH-GEAR rainfall data sources at borehole locations within visual category A

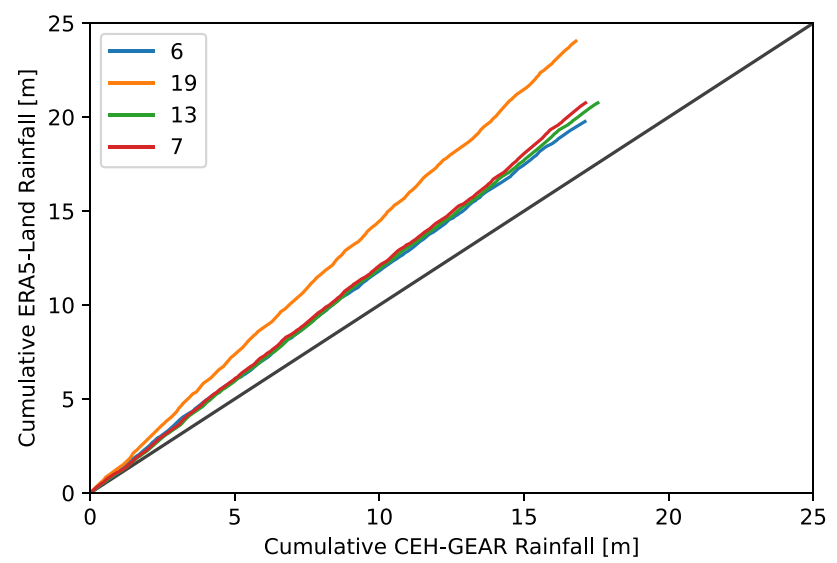

Fig. 11 Double mass plot of ERA5-Land and CEH-GEAR rainfall data sources at borehole locations within visual category B

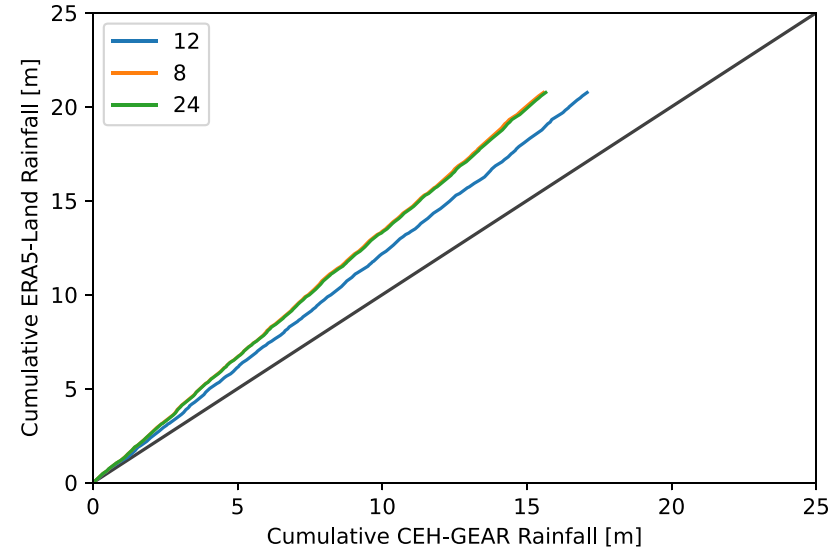

Fig. 12 Double mass plot of ERA5-Land and CEH-GEAR rainfall data sources at borehole locations within visual category $\mathrm{C}$ 
Fig. 13 Meteorological STL variance comparison between ERA5-Land and CEH-GEAR data sources at borehole locations. Marker colour denotes data source: purple is CEHGEAR and orange is ERA5Land. Marker shape denotes meteorological data: circle is effective rainfall, diamond is rainfall and cross is actual or potential evaporation for $\mathrm{CEH}$ GEAR or ERA5-Land

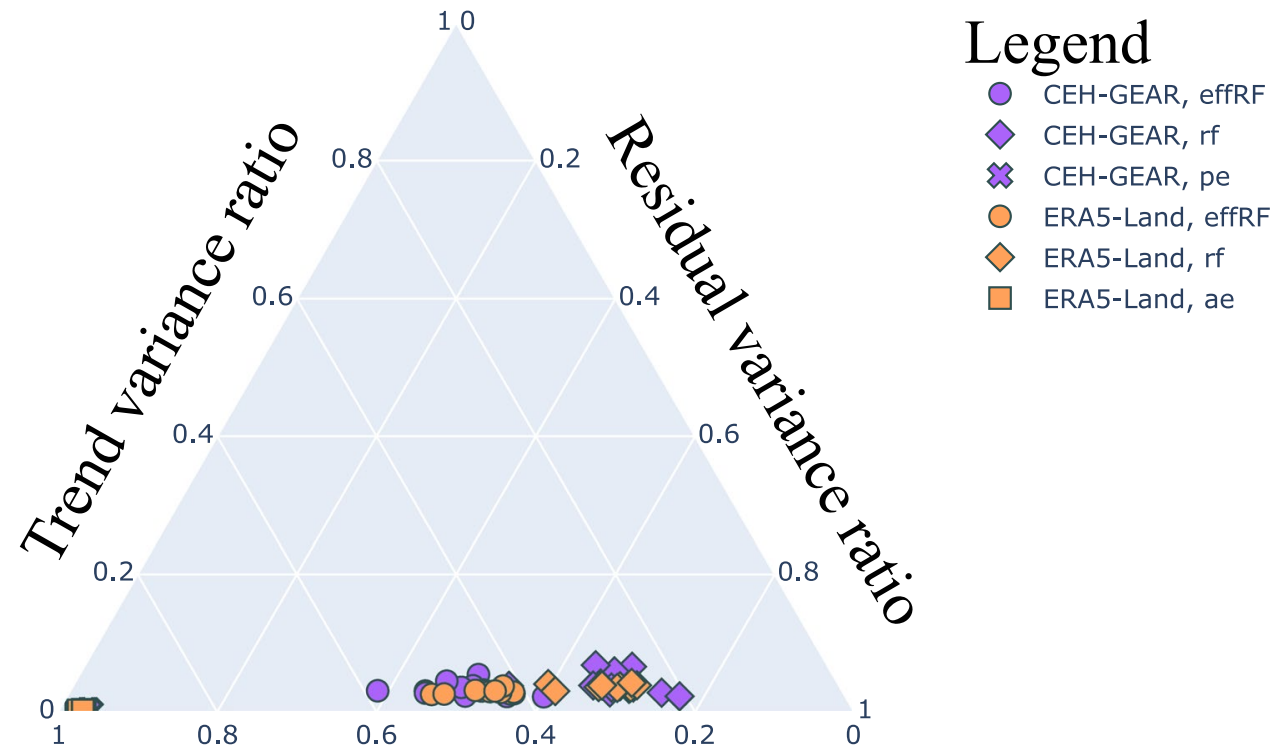

\section{Seasonal variance ratio}

Acknowledgements Hughes publishes with the permission of the Executive Director of BGS (UKRI).

Funding Colyer is funded under the NERC Imperial SSCP DTP grant no. NE/L002515/1

Open Access This article is licensed under a Creative Commons Attribution 4.0 International License, which permits use, sharing, adaptation, distribution and reproduction in any medium or format, as long as you give appropriate credit to the original author(s) and the source, provide a link to the Creative Commons licence, and indicate if changes were made. The images or other third party material in this article are included in the article's Creative Commons licence, unless indicated otherwise in a credit line to the material. If material is not included in the article's Creative Commons licence and your intended use is not permitted by statutory regulation or exceeds the permitted use, you will need to obtain permission directly from the copyright holder. To view a copy of this licence, visit http://creativecommons.org/licenses/by/4.0/.

\section{References}

Aalto J, Riihimäki H, Meineri E, Hylander K, Luoto M (2017) Revealing topoclimatic heterogeneity using meteorological station data. Int J Climatol 37:544-556. https://doi.org/10.1002/joc.5020

Allen DJ, Brewerton LJ, Coleby LM, Lewis MA, MacDonald AM, Wagstaff SJ, Williams AT (1997) The physical properties of major aquifers in England and Wales. British Geological Survey, Keyworth, UK

Allen DJ, Newell AJ, Butcher AS (2010) Preliminary review of the geology and the hydrogeology of the Eden DTC sub-catchments. British Geological Survey Open Report, BGS, Keyworth, UK

Arthurton RS, Wadge AJ (1981) Geology of the country around Penrith: memoir for 1:50 000 geological sheet 24. Institute of Geological Sciences, London

Bianchi M, Kearsey T, Kingdon A (2015) Integrating deterministic lithostratigraphic models in stochastic realizations of subsurface heterogeneity: impact on predictions of lithology, hydraulic heads and groundwater fluxes. J Hydrol 531:557-573

Bloomfield JP, Marchant BP, Bricker SH, Morgan RB (2015) Regional analysis of groundwater droughts using hydrograph classification. Hydrol Earth Syst Sci 19:4327-4344. https://doi.org/10.5194/ hess-19-4327-2015

Boutt DF (2017) Assessing hydrogeologic controls on dynamic groundwater storage using long-term instrumental records of water table levels. Hydrol Process 31:1479-1497. https://doi.org/10.1002/ hyp.11119

Box GEP, Jenkins GM, Reinsel GC, Ljung GM (2016) Time series analysis: forecasting and control, 5th edn. Wiley, Hoboken, NJ

British Geological Survey - Enquiries (2021) Single Onshore Borehole Index, BGS, Keyworth, UK

Butcher AS, Lawrence AR, Jackson CR, Cunningham J, Cullis E, Hasan K, Ingram J (2003) Investigation of rising nitrate concentrations in groundwater in the Eden Valley, Cumbria: Phase 1 Project Scoping Study. BGS, Keyworth, UK; Environmental Agency, London

Butcher AS, Lawrence A, Jackson C, Cullis E, Cunningham J, Hasan $\mathrm{K}$, Ingram J (2006) Investigating rising nitrate concentrations in groundwater in the Permo-Triassic aquifer, Eden Valley, Cumbria, UK. Geol Soc London Spec Publ 263:285-296. https://doi.org/10. 1144/gsl.sp.2006.263.01.16

Butcher AS, Lawrence A, Gallagher A, Burke S, Ingram J, Merrin P (2008) Investigation of rising nitrate concentrations in groundwater in the Eden Valley, Cumbria: 3, saturated zone studies. Project SC030113, Environmental Agency, London; BGS, Keyworth, UK

Cai Z, Ofterdinger U (2016) Analysis of groundwater-level response to rainfall and estimation of annual recharge in fractured hard rock aquifers, NW Ireland. J Hydrol 535:71-84. https://doi.org/ 10.1016/j.jhydrol.2016.01.066

Cleveland RB, Cleveland WS, McRae JE, Terpenning I (1990) STL: a seasonal-trend decomposition procedure based on LOESS. J Off Stat 6:3-73

Delbart C, Valdes D, Barbecot F, Tognelli A, Richon P, Couchoux L (2014) Temporal variability of karst aquifer response time established by the sliding-windows cross-correlation method. J Hydrol 511:580-588. https://doi.org/10.1016/j.jhydrol.2014.02.008 
Freeze RA, Cherry JA (1979) Groundwater. Prentice-Hall, Englewood Cliffs, NJ

Giese M, Haaf E, Heudorfer B, Barthel R (2020) Comparative hydrogeology-reference analysis of groundwater dynamics from neighbouring observation wells. Hydrol Sci J 65:1685-1706. https:// doi.org/10.1080/02626667.2020.1762888

Hiscock KM (2014) Hydrogeology: principles and practice. Wiley Blackwell, Hoboken, NJ

Hughes RA (2003a) Carboniferous rocks and Quaternary deposits of the Appleby district (part of Sheet 30, England and Wales). British Geological Survey research report, BGS, Keyworth, UK

Hughes RA (2003b) Permian and Triassic rocks of the Appleby district (part of Sheet 30, England and Wales). British Geological Survey research report, BGS, Keyworth, UK

Ingram J (1978) The Permo-Triassic sandstone aquifers of North Cumbria. Hydrogeological report, North West Water Authority, Warrington, $\mathrm{PA}$,

Kovács J, Márkus L, Szalai J, Kovács IS (2015) Detection and evaluation of changes induced by the diversion of River Danube in the territorial appearance of latent effects governing shallowgroundwater fluctuations. J Hydrol 520:314-325. https://doi.org/ 10.1016/j.jhydrol.2014.11.052

Lafare AEA, Hughes AG, Peach DW (2014) Eden Valley observation boreholes: hydrogeological framework and groundwater level time series analysis. British Geological Survey Internal Report, OR/14/041, BGS, Keyworth, UK

Lafare AEA, Peach DW, Hughes AG (2021) Use of point scale models to improve conceptual understanding in complex aquifers: an example from a sandstone aquifer in the Eden Valley, Cumbria, UK. Hydrol Process 35. https://doi.org/10.1002/hyp.14143

Lafare AEA, Peach DW, Hughes AG (2016) Use of seasonal trend decomposition to understand groundwater behaviour in the Permo-Triassic Sandstone aquifer, Eden Valley, UK. Hydrogeol J 24:141-158. https://doi.org/10.1007/s10040-015-1309-3

Leedal D, Weerts AH, Smith PJ, Beven KJ (2013) Application of databased mechanistic modelling for flood forecasting at multiple locations in the Eden catchment in the National Flood Forecasting System (England and Wales). Hydrol Earth Syst Sci 17:177-185. https://doi.org/10.5194/hess-17-177-2013

Lovelock PER, Price M, Tate TK (1975) Groundwater conditions in the Penrith Sandstone at Cliburn, Westmoreland. J Inst Water Eng Sci 29:157-174
Medici G, Boulesteix K, Mountney NP, West LJ, Odling NE (2015) Palaeoenvironment of braided fluvial systems in different tectonic realms of the Triassic Sherwood Sandstone Group, UK. Sediment Geol 329:188-210. https://doi.org/10.1016/j.sedgeo.2015.09.012

Medici G, West LJ, Mountney NP (2019) Sedimentary flow heterogeneities in the Triassic U.K. Sherwood Sandstone Group: insights for hydrocarbon exploration. Geol J 54:1361-1378. https://doi. org/10.1002/gj.3233

Moon SK, Woo NC, Lee KS (2004) Statistical analysis of hydrographs and water-table fluctuation to estimate groundwater recharge. J Hydrol 292:198-209. https://doi.org/10.1016/j.jhydrol.2003.12. 030

Muñoz Sabater J (2019) ERA5-Land monthly averaged data from 1981 to present. Earth Syst Sci Data 13:4349-4383

Raupach MR, Finnigan JJ (1995) Scale issues in boundary-layer meteorology: surface energy balances in heterogeneous terrain. Hydrol Process 9:589-612. https://doi.org/10.1002/hyp.3360090509

Shamsudduha M, Chandler RE, Taylor RG, Ahmed KM (2009) Recent trends in groundwater levels in a highly seasonal hydrological system: the Ganges-Brahmaputra-Meghna Delta. Hydrol Earth Syst Sci 13:2373-2385

Stone P, Millward D, Young B, Merritt JW, Clarke SM, McCormac M, Lawrence DJD (2010) British regional geology: northern England, 5th edn. British Geological Survey, Keyworth, UK

Tanguy M, Dixon H, Prosdocimi I, Morris DG, Keller VDJ (2019) Gridded estimates of daily and monthly areal rainfall for the United Kingdom (1890-2017) [CEH-GEAR]. https://doi.org/10. 5285/ee9ab43d-a4fe-4e73-afd5-cd4fc4c82556

Wang L, Butcher AS, Stuart ME, Gooddy DC, Bloomfield JP (2013) The nitrate time bomb: a numerical way to investigate nitrate storage and lag time in the unsaturated zone. Environ Geochem Health 35:667-681. https://doi.org/10.1007/s10653-013-9550-y

Younger PL, Milne CA (1997) Hydrostratigraphy and hydrogeochemistry of the Vale of Eden, Cumbria, UK. Proc Yorkshire Geol Soc $51: 349-366$

Publisher's note Springer Nature remains neutral with regard to jurisdictional claims in published maps and institutional affiliations. 